\title{
Diffuse Large B-Cell Lymphoma Complicated by Small Bowel Obstruction after Radiotherapy: a Case Study
}

\author{
Diah Ari Safitri*, Kartika Widayati Taroeno-Hariadi, Johan Kurnianda, Ibnu Purwanto \\ Department of Internal Medicine, Faculty of Medicine, Universitas Gadjah Mada/ Dr. \\ Sardjito Hospital, Yogyakarta
}

DOI: http://dx.doi.org/10.19106/JMedSci004803201603

\begin{abstract}
Although the spleen is frequently involved in disseminated non-Hodgkin's lymphoma $(\mathrm{NHL})$, splenic presentation as the initial or only site of disease is uncommon. Treatment modalities include surgery, chemotherapy, and radiation therapy. The priority of cancer follow up is to perform surveillance for recurrent cancer and evaluation of treatment response. Side effects of treatment are frequently missed or overlooked. A 66-year-old woman was presented to our hospital with a month history of spleen enlargement. On physical examination the spleen was palpated at Schuffner 2. Abdominal MSCT scan was suggestive of lymphoma. Surgery revealed adhesion and obstruction of the stomach. Biopsy and gastrojejunostomy shunting were done, but splenectomy was difficult. The pathology anatomy findings confirmed the diagnosis of diffuse non Hodgkin's lymphoma large B-cell type. Immunohistochemistry showed positive CD3 and CD20. She underwent 6 cycles of rituximab, cyclophosphamide, adriamycin, vincristine, and prednisolone (RCHOP) chemotherapy. CT evaluation done 7 months later revealed that the hilus lienalis lymph nodes and spleen has decrease in size. However, a lumbosacral x-ray done due to back pain revealed metastasis on her $1^{\text {st }}$ and $2^{\text {nd }}$ lumbal spine. After a single fraction of radiotherapy, nausea, vomiting and abdominal distension occurred. A 3 position abdominal $\mathrm{x}$-ray revealed signs of small bowel obstruction. After surgery she has received 9 cycles of zoledronic acid and remained in good condition and ambulatory. Splenic presentation as the initial or only site of non-Hodgkin's lymphoma (NHL) is uncommon. Acute small bowel obstruction and fistula due to palliative radiation therapy for bone metastasis needs prompt and appropriate treatment.
\end{abstract}

\section{ABSTRAK}

Meskipun lien sering terlibat pada limfoma non-Hodgkin diseminata, keterlibatan lien sebagai awal penyakit atau satu-satunya organ yang terkena adalah jarang. Modalitas terapi meliputi pembedahan, kemoterapi, dan terapi radiasi. Prioritas follow up kanker adalah untuk melakukan surveilans pada kanker yang rekuren dan evaluasi respon terapi. Efek samping terapi seringkali tidak dikenali atau terlewat. Seorang wanita usia 66 tahun datang ke RS Sardjito dengan riwayat pembesaran lien sejak 1 bulan. Pada pemeriksaan palpasi didapatkan pembesaran lien sebesar Schuffner 2. MSCT scan abdomen dicurigai suatu limfoma. Pada saat pembedahan didapatkan obstruksi perut dengan pelekatan. Dilakukan biopsi dan shunt gastrojejunostomy, namun sulit dilakukan splenektomi. Pemeriksaan patologi anatomi mengkonfirmasi diagnosis limfoma non-Hodgkin tipe large

Corresponding author: ifidas2@gmail.com 
B-cell difus. Imunohistokimia menunjukkan CD3 dan CD20 positif. Pasien menjalani 6 siklus kemoterapi dengan rituximab, siklofosfamid, adriamycin, vincristine, dan prednisolon (RCHOP). Evaluasi CT 7 bulan kemudian menunjukkan bahwa pembesaran limfonodi hillus lienalis dan lien berkurang. Namun demikian, foto $x$-ray lumbosakral yang dilakukan karena keluhan nyeri pinggang menunjukkan adanya metastasis pada vertebra lumbalis 1 dan 2. Setelah dilakukan radioterapi fraksi tunggal, timbul mual, muntah, dan distensi abdomen. Foto $x$-ray abdomen 3 posisi menunjukkan tanda obstruksi usus kecil. Setelah dilakukan operasi, pasien menerima 9 siklus zoledronic acid dan menunjukkan kondisi baik. Manifestasi lien sebagai awal atau satu-satunya lokasi limfoma non-Hodgkin's jarang dijumpai. Obstruksi usus kecil akut dan fistula yang disebabkan oleh terapi radiasi paliatif untuk metastasis tulang memerlukan terapi yang cepat dan tepat.

Keywords: Non Hodgkin's Lymphoma, spleen, radiation therapy, small bowel obstruction

\section{INTRODUCTION}

Non-Hodgkin's lymphoma (NHL) is one of the most common cancers in the United States, accounting for about $4.3 \%$ of all new cancer cases. NHL is most frequently diagnosed among people aged $65-74 .{ }^{1}$ The most common subtype of NHL is diffuse large B-cell lymphoma (DLBCL), accounting for approximately $30 \%$ of cases. ${ }^{2}$ Although the spleen is frequently involved in disseminated NHL, splenic presentation as the initial or only site of disease is uncommon. The true incidence of splenic lymphoma is difficult to estimate because of the variable definition of this disease, however, the diagnosis of primary lymphoma of the spleen should be limited to involvement of only the spleen and splenic hilum $^{3}$

A combination of rituximab and the cyclophosphamide, adriamycin, vincristine, and prednisolone (RCHOP) regimen has become the standard treatment for DLBCL because it greatly improves the outcome of patients with this disease, especially of young patients in the low-risk group. ${ }^{2}$ Radiotherapy is used in the treatment of NHL to improve outcomes of DLBCL patients who achieved a complete response (CR) to $\mathrm{RCHOP}^{4}$ Radiotherapy is also used in treatment of complication of the disease such as in bone metastases. ${ }^{5}$ Herein, we present the case of a primary splenic DLBCL patient who was treated with chemotherapy RCHOP. Complication of small bowel obstruction occurred after a single fraction of irradiation to treat bone metastases, which was detected by x-ray after 6 cycles of chemotherapy. The complication was treated via surgery.

\section{CASE REPORT}

A 66-year-old woman was presented to our hospital with a month history of spleen enlargement. On physical examination the spleen was palpated at Schuffner 2, with no other enlargement of lymph nodes. Abdominal MSCT scan was suggestive of lymphoma and confirmed that there was no paraaortic lymph node enlargement. There were intra and extra spleen hypodense lesions with indistinct border. The spleen's remainder parenchyma showed slight enhancement. (FIGURE 1). Surgery done 3 months later, revealed adhesion and obstruction of the stomach. Biopsy and gastrojejunostomy were done, but splenectomy was difficult to be performed.

The pathology anatomy findings confirmed the diagnosis of diffuse non Hodgkin's lymphoma large B-cell type. 
Immunohistochemistry showed positive CD3 and CD20. She underwent 6 cycles of RCHOP chemotherapy. CT evaluation was done 7 months later showed that her hilus lienalis lymph nodes and spleen has decrease in size and was classified as Ann-Arbour stage IVS (FIGURE 2). She was admitted to the hospital due to back pain 2 weeks after her last evaluation. A lumbosacral radiograph revealed metastasis on her $1^{\text {st }}$ and $2^{\text {nd }}$ lumbal vertebrae. Radiotherapy was given once, but 2 days after radiotherapy she complained of nausea and vomiting. The physical examination showed abdominal distension. A 3 position abdominal radiograph revealed coil spring, heringbone, short air-fluid level

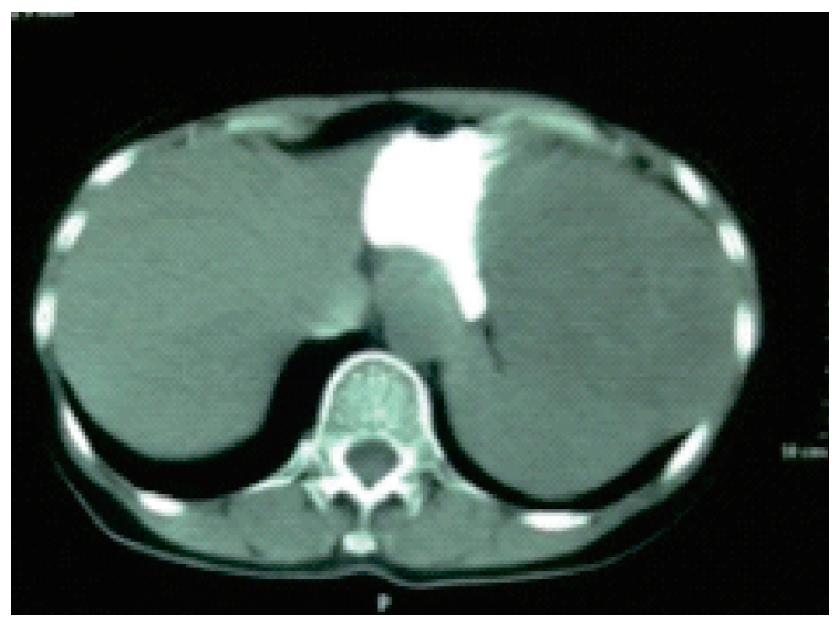

and stepladder appearances, as signs of small bowel obstruction (FIGURE 3). She underwent surgery which revealed adhesion in the abdominal wall, a band which entrapped the illeum at about $80 \mathrm{~cm}$ from the ligament of Treitz, a grade 3 adhesion of jejunum to the ventral of abdomen and stomach, and a gaster-jejunum fistula which may be caused by radiation. Splenectomy was not able to be performed. After surgery, she has received 9 cycles of zoledronic acid. On evaluation, the thoracic, lumbar, and sacral radiograph showed no signs of bone metastases. She was in good condition and ambulatory. Time of follow up was 30 months.

FIGURE 1. Abdominal CT scan before chemotherapy showing enlargement of spleen

FIGURE 2. Abdominal CT scan after completion of chemotherapy showing a decreased spleen size

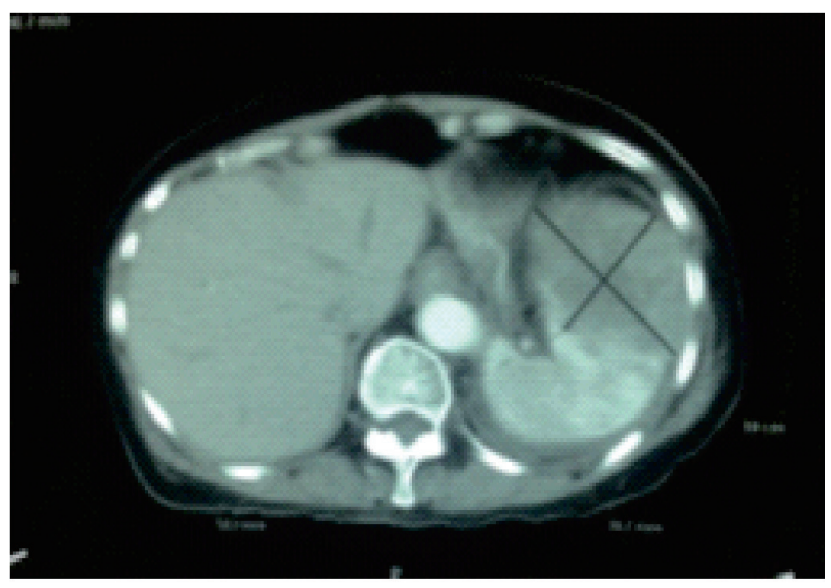



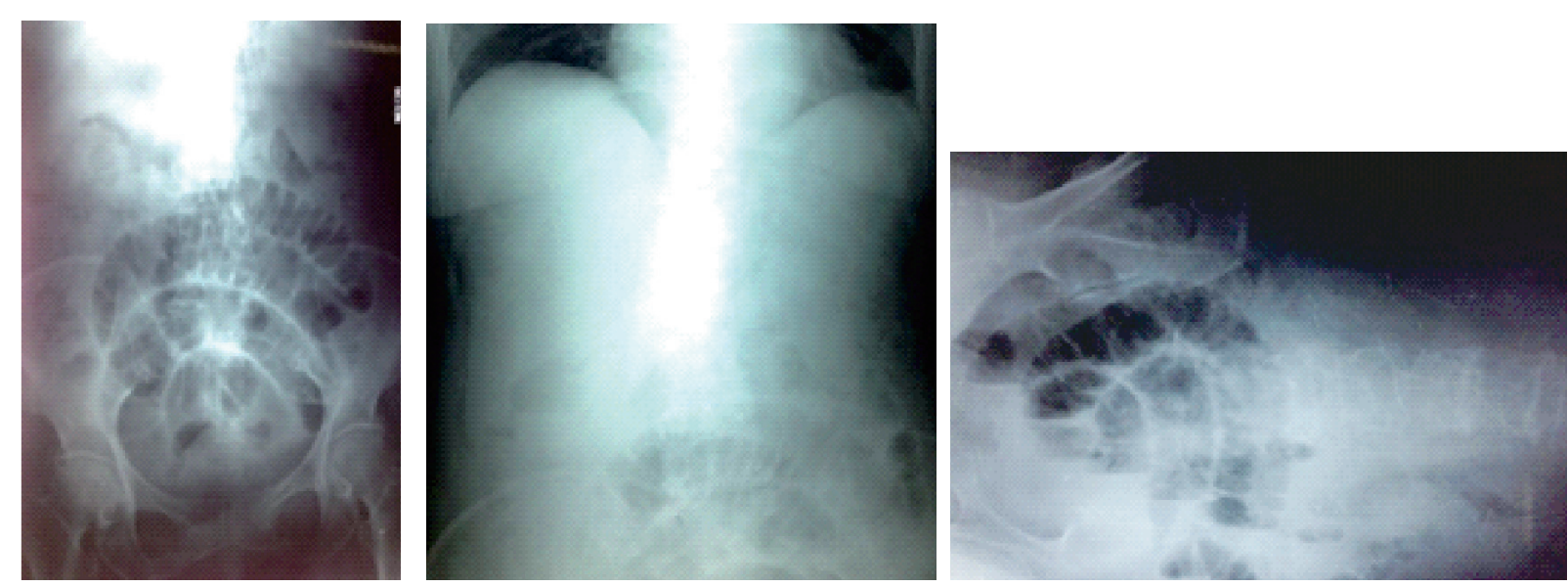

FIGURE 3. Abdominal x-rays showing signs of small bowel obstruction

\section{DISCUSSION}

\section{Primary splenic diffuse large $B$-cell lymphoma}

Splenic involvement is found at initial presentation of lymphoma in $10-40 \%$ of patients with NHL. Splenic involvement is typically diffuse, and only a small minority of cases manifest nodules larger than $1 \mathrm{~cm}$ in diameter. Diffuse infiltration may be present in spleens of normal size. Marked splenomegaly almost always indicates infiltration. ${ }^{6}$ Primary splenic diffuse large B-cell lymphoma, an uncommon type of non-Hodgkin lymphoma, has been investigated only in small patient series before the rituximab era. Patients may present with abdominal pain, B symptoms, splenomegaly, splenic masses, and high lactate dehydrogenase (LDH) levels. As much as 61\% had stage I or II disease. The diagnosis can be made by core-needle biopsy or diagnostic splenectomy. In patients with early-stage disease, splenectomy at diagnosis improves survival. ${ }^{7}$ Diagnosis of these lymphomas has been reliant on the histopathologic examination of the spleen. ${ }^{8}$

In our case, it seemed that the first presentation of the disease was enlargement of spleen without any evidence of involvement in other sites. Our patient's diagnosis was made by biopsy of the spleen, but splenectomy at diagnosis was not done due to adhesion. However, a PET-CT was not done. PET-CT has been recommended for routine staging of FDG-avid, nodal lymphoma. In addition, splenic involvement is best determined by PET-CT and may be characterized by homogeneous splenomegaly, diffuse infiltration with milliary lesions, focal nodular lesions, or a large solitary mass. PET-CT leads to change in stage in $10 \%$ to $30 \%$ of patients, more often upstaging, although alteration in management occurs in fewer patients, with no demonstrated impact on overall outcome. As a result, diffuse large B-cell lymphoma patients can be spared a staging bone marrow biopsy, and a routine chest $\mathrm{x}$-ray is unnecessary for staging. ${ }^{9}$

\section{Role of chemotherapy on DLBCL}

The treatment option for primary splenic DLBCL generally involves six to eight cycles of chemotherapy with the R-CHOP regimen (rituximab, cyclophosphamide, doxorubicin, vincristine and prednisone). ${ }^{10,2}$ For patients who are refractory to chemotherapy or are inoperable, therapeutic splenic irradiation (SI) might be a reasonable and possibly the 
only treatment option with curative intention. However, the efficacy and safety of SI in treating primary splenic DLBCL remain uncertain and need further investigation. ${ }^{2}$ Brox \& Shustik suggests that the prognosis of NHL of the spleen, when pathologically staged, may have a favorable prognosis which approximates that seen with limited stage NHL at other sites. ${ }^{3}$ splenic presentation as the initial or only site of disease is uncommon. The true incidence of splenic lymphoma is difficult to estimate because of the variable definition of this disease, however, the diagnosis of primary lymphoma of the spleen should be limited to involvement of only the spleen and splenic hilum. Using this restricted definition, our experience suggests that the prognosis of NHL of the spleen, when pathologically staged, may have a favorable prognosis which approximates that seen with limited stage NHL at other sites.

\section{Role of radiotherapy on DLBCL}

Since the $20^{\text {th }}$ century, radiotherapy (RT) has been used for treatment of symptomatic splenomegaly. Splenomegaly occurs in association with hematologic disorders. A study of 122 patients receiving 246 RT courses because of symptomatic splenomegaly revealed those who received $\mathrm{RT}$ were patients with chronic myelogenous leukemia (CML), chronic lymphocytic leukemia (CLL), osteomyelofibrosis (OMF), polycythemia vera (PV), acute myelogenous leukemia, idiopathic thrombocytopenic purpura (ITP), non-Hodgkin lymphoma (NHL), and multiple myeloma (MM). Patients were treated with Cobalt-60 gamma radiation or $5-15 \mathrm{MV}$ photons. The fraction size ranged from 10-200 cGy and the total dose per treatment course from 30-1600 cGy. Significant pain relief was achieved for $74.8 \%$ of the RT courses given for splenic pain. At least 50\% regression was attained for $77 \%$ of the RT courses given for
SM. 36 patients died within 2 months due to the terminal nature of their disease. Of the RT courses applied for cytopenia, $73.6 \%$ achieved a significant improvement of hematological parameters and reduction of transfusion need. The present analysis documents the efficacy of RT. ${ }^{11}$

A meta-analysis study supported the role of radiotherapy as an option for DLBCL patients who achieve a CR to RCHOP, especially those with bulky disease. ${ }^{4}$ Another systematic review with meta-analysis by Dos Santos et al., ${ }^{12}$ showed that RT enhances progression free survival after chemotherapy with no impact on overall response rate and overall survival for aggressive and localized NHL. ${ }^{12}$ Another role for radiotherapy consists of palliative treatment for bone metastases to relieve pain, preserve functions, and maintain skeletal integrity. Other currently available pain-relieving strategies include opioid-based analgesia, bisphosphonates, and acupuncture. External beam radiotherapy (EBRT) can provide significant palliation of painful bone metastases in $50-80 \%$ of patients, with up to one-third of patients achieving complete pain relief at the treated site. ${ }^{5}$

The common the appropriate fractionation schemes can be divided as short-course and long-course. Jeremic et al., investigated the efficacies of three short-course RT regimens (4 Gy vs 6 Gy vs 8 Gy) in the treatment of painful bone metastasis and confirmed that 8 Gy might be the lowest optimal single fraction. ${ }^{13}$ The long-course regimens usually include 30 Gy in 10 fractions, 20 Gy in 5 fractions, $24 \mathrm{~Gy}$ in 6 fractions, etc. It has been reported that $30 \mathrm{~Gy}$ in 10 fractions is the most common scheme in the United States, 20 Gy in 5 fractions is the most common scheme in Canada, and a short-course scheme of 8 Gy in a single fraction remains most common in some European countries. ${ }^{5}$ 
$\mathrm{Zhu}^{5}$ reviewed some prospective randomized trials that had compared the short-course or long-course regimens of palliative radiotherapy for painful bone metastases. Randomized trials from different areas in the world have demonstrated that single-fraction radiation therapy is sufficient to achieve palliation of painful bone metastases with optimized convenience for both patients and caregivers. A single dose of 8 Gy seems to become the standard treatment. However, patients receiving short-course radiotherapy may receive remarkably more reirradiations. ${ }^{5,14}$ the most common primary sites being breast, prostate, and lung. Important in palliative treatment is to reach a maximal effect with the minimal treatment. The aim of palliation for cancer patients is to increase the quality of their remaining life.Conclusions. The management of bone pain includes analgesics, local treatment(radiation, surgery $\mathrm{A}$ systematic review analyzing the effectiveness and safety of radiotherapy plus intravenous bisphosphonates versus radiotherapy alone for treating bone metastasis showed that the combine treatment radiotherapy plus intravenous bisphosphonates for bone metastases is safe and effective. ${ }^{15}$

\section{Complications of radiotherapy on small bowel}

Our patient underwent radiotherapy due to bone pain which was suspected to be caused by bone metastases on her $1^{\text {st }}$ and $2^{\text {nd }}$ lumbar spine. She has had radiotherapy once before small bowel obstruction occured. Surgery reports stated that there was a possibility that the gastro-jejunal fistula was caused by radiation. The adhesion however may be caused by the cancer or worsened by radiation to the bone (lumbar spine), since adhesions were already found on the initial biopsy surgery, but response to chemotherapy was noted by decreasing size of the spleen. Clinical manifestations of gastrointestinal radiation injury can present acutely during or soon following radiotherapy due to acute mucosal injury and inflammation or they can present insidiously within few months or years after radiotherapy due to a chronic process of transmural fibrosis and vascular sclerosis. ${ }^{16}$ there is an increasing emphasis on the efficacy and safety aspects of cancer therapy. Radiation therapy is a common treatment for a wide variety of cancers, either alone or in combination with other treatments. Ionising radiation injury to the gastrointestinal tract is a frequent side effect of radiation therapy and a considerable proportion of patients suffer acute or chronic gastrointestinal symptoms as a result. These side effects often cause morbidity and may in some cases lower the efficacy of radiotherapy treatment. Radiation injury to the gastrointestinal tract can be minimised by either of two strategies: technical strategies which aim to physically shift radiation dose away from the normal intestinal tissues, and biological strategies which aim to modulate the normal tissue response to ionising radiation or to increase its resistance to it. Although considerable improvement in the safety of radiotherapy treatment has been achieved through the use of modern optimised planning and delivery techniques, biological techniques may offer additional further promise. Different agents have been used to prevent or minimize the severity of gastrointestinal injury induced by ionising radiation exposure, including biological, chemical and pharmacological agents. In this review we aim to discuss various technical strategies to prevent gastrointestinal injury during cancer radiotherapy, examine the different therapeutic options for acute and chronic gastrointestinal radiation injury and outline some examples of research directions and considerations for prevention at a preclinical level. 
Acute radiation-induced small bowel disease usually presents with colicky abdominal pain, bloating, loss of appetite, nausea, diarrhea and fecal urgency during or shortly after a course of radiotherapy. Almost all patients receiving pelvic or abdominal radiotherapy experience some form of gastrointestinal symptoms. Patients usually notice these symptoms during the second week of treatment (when tissue damage and inflammation is probably at a maximum), and they characteristically peak by the fourth to fifth week (when histological changes are stable or improving). ${ }^{17}$

Obstruction usually affects the small bowel or, after pelvic radiotherapy, the sigmoid. Several factors may contribute in individual patients. It may develop as a result of benign causes such as changes in intestinal transit, medical causes, adhesions or radiotherapy-induced fibrosis, or malignant causes such as recurrent cancer or peritoneal carcinomatosis. Acute small bowel obstruction should be managed conservatively initially with analgesia, intravenous fluids, nutritional support and nasogastric aspiration unless there is suspicion of strangulation requiring emergency surgery. Cross-sectional imaging, which sometimes is difficult to interpret accurately, may be helpful to estimate the level of obstruction and whether it is complete or incomplete. The possibility of multiple sites of partial obstruction needs to be carefully considered as this may limit surgical options. ${ }^{18}$

Chronic small bowel radiation disease typically develops between 18 months and 6 years after a completed course of radiotherapy, but has been reported to present up to 30 years later. ${ }^{17}$ Late radiation injury to the bowel, which may result in bleeding, frequency, fistula formation, and, particularly in small bowel, obstruction, is caused by damage to the entire thickness of the bowel wall. ${ }^{1}{ }^{1}$ the late effects of radiation on three gastrointestinal sites, the esophagus, the stomach, and the bowel, are described. Esophageal dysmotility and benign stricture following esophageal irradiation are predominantly a result of damage to the esophageal wall, although mucosal ulcerations also may persist following high-dose radiation. The major late morbidity following gastric irradiation is gastric ulceration caused by mucosal destruction. Late radiation injury to the bowel, which may result in bleeding, frequency, fistula formation, and, particularly in small bowel, obstruction, is caused by damage to the entire thickness of the bowel wall, and predisposing factors have been identified. For each site a description of the pathogenesis, clinical findings, and present management is offered. Simple and reproducible endpoint scales for late toxicity measurement were developed and are presented for each of the three gastrointestinal organs. Factors important in analyzing late complications and future considerations in evaluation and management of radiation-related gastrointestinal injury are discussed."'Int J Radiat Oncol Biol Phys. 1995 Mar 30;31(5 Prostprandial pain, acute or intermittent small bowel obstruction, nausea, anorexia, weight loss, bloating, diarrhea, steatorrhea and malabsorption of selected or multiple nutrients, are also symptoms of chronic enteropathy. These can arise from damage to the small bowel itself or associated phenomena such as bile salt malabsorption, bacterial overgrowth or lactose intolerance. ${ }^{17}$

Deitel et al.,${ }^{20}$ reported that hospitalization was required for intestinal injuries following radiotherapy for carcinoma of the cervix, endometrium, ovary, bladder, rectum, and other primary sites. Intestinal complications included stenosis, perforation, rectal ulcer, and rectovaginal, ileovaginal, and ileovesical fistula. Surgery, such as bowel resections, colostomy, adhesiolysis, ileocolic bypass, and Hartmann's procedure for sigmoid perforation, 
was indicated for some complications due to radiotherapy. ${ }^{20}$ endometrium, ovary, bladder, rectum, and other primary sites. Intestinal complications included stenosis, perforation, rectal ulcer, and rectovaginal, ileovaginal, and ileovesical fistula; 27 patients had multiple intestinal complications. Operation was necessary in 33 patients, as follows: bowel resections, 18; colostomy alone, five; adhesiolysis, five; ileocolic bypass, three; and Hartmann's procedure for sigmoid perforation, two. Five anastomotic leaks and six postoperative deaths occurred. Causes of death among the remaining patients included residual cancer (ten

\section{CONCLUSION}

Splenic presentation as the initial or only site of non-Hodgkin's lymphoma (NHL) is uncommon. In our case, CT evaluation showed decrease in spleen size after chemotherapy. After 9 cycles of zoledronic acid, there were no signs of bone metastases on radiographic findings. However, response assessment using PET-CT as the preferred modality was not performed.

Radiotherapy to treat painful bone metastasis is needed to improve quality of life. However, complications should not be overlooked. In this case, acute small bowel injury due to radiation needs prompt treatment, obstruction was treated with surgery.

\section{ACKNOWLEDGEMENT}

We would like to thank dr. Agus Barmawi, SpB-KBD from Department of Surgery, Sardjito General Hospital for his support on the preparation of this manuscript. We would also like to thank the patient on whom this case report is based.

\section{REFERENCE}

1. Howlader N, Noone A, Krapcho M, Garshell J, Miller D, Altekruse S, et al. SEER Cancer Statistics Review, 1975-2012, National Cancer Institute. [Internet]. 2015. Available from: http://seer.cancer.gov/csr/1975_2012/, based on November 2014 SEER data submission, posted to the SEER web site, April 2015.

2. Lin $\mathrm{YC}$, Chen HC, Cheng SB, Hwang WL, Wang RC, Teng CL. Splenic irradiationinduced gastric variceal bleeding in a primary splenic diffuse large B-cell lymphoma patient: a rare complication successfully treated by splenectomy with short gastric vein ligation. World J Surg Oncol 2012; 10(1):150. http://dx.doi.org/ 10.1186/1477-7819-10-150

3. Brox A, Shustik C. Non-Hodgkin's lymphoma of the spleen. Leuk Lymphoma 1993; 11(3-4):165-71. http://dx.doi. org/10.3109/10428199309086992

4. Hu C, Deng C, Zou W, Zhang G, Wang J. The role of consolidative radiotherapy after a complete response to chemotherapy in the treatment of diffuse large B-cell lymphoma in the rituximab era: results from a systematic review with a meta-analysis. Acta Haematol 2015; 134(2):111-8. http://dx.doi. org/10.1159/000370096

5. Zhu YJ. Palliative radiotherapy for painful bone metastases: short-course or longcourse? Ann Palliat Med 2012; 1(1):78-80. http://dx.doi.org/10.3978/j.issn.22245820.2011.10.03

6. Manzella A, Borba-filho P, D'Ippolito G, Farias M. Abdominal manifestations of lymphoma: spectrum of imaging features. ISRN Radiol 2013; 483069:1-12. http://dx.doi.org/10.5402/2013/483069

7. Bairey O, Shvidel L, Perry C, Dann E, Ruchlemer R, Tadmor T, et al. Characteristics of primary splenic diffuse large B-cell lymphoma and role of splenectomy 
in improving survival. Cancer 2015; 121(17):2909-16. http://dx.doi.org/10.1002/ cncr.29487

8. Behdad A, Bailey NG. Diagnosis of splenic B-cellymphomas in the bonemarrow: areview of histopathologic, immunophenotypic, and genetic findings. Arch Pathol Lab Med 2014; 138(10):1295-301. http://dx.doi.org/10.5858/ arpa.2014-0291-CC

9. Cheson BD, Fisher RI, Barrington SF, Cavalli F, Schwartz LH, Zucca E, et al. Recommendations for initial evaluation, staging, and response assessment of Hodgkin and Non-Hodgkin lymphoma: the lugano classification. J Clin Oncol 2014; 32(27):3059-68. http://dx.doi.org/10.1200/ JCO.2013.54.8800

10. Tanaka M, Tsunoda S, Inoue K, Izumi T, Yamamoto T, Hoshi S, et al. Clinical analysis of 3 cases with primary splenic diffuse large B-cell lymphoma. Rinsho Ketsueki 2011; 52(8):703-7. http://dx.doi.org/10.1007/ s00066-011-2252-4

11. Kriz J, Micke O, Bruns F, Haverkamp U, Mücke R, Schäfer U, et al. Radiotherapy of splenomegaly: a palliative treatment option for a benign phenomenon in malignant diseases. Strahlenther Onkol 2011; 187(4):221-4 http://dx.doi.org/ 10.1007/s00066-011-22524

12. Dos Santos LV, Lima JP, Lima CS, Sasse EC, Sasse AD. Is there a role for consolidative radiotherapy in the treatment of aggressive and localized Non-Hodgkin Lymphoma? A systematic review with meta-analysis. BMC Cancer 2012; 12:288.

http://dx.doi.org/10.1186/1471-2407-12-288

13. Jeremic B, Shibamoto Y, Acimovic L, Milicic B, Milisavljevic S, Nikolic N, et al. A randomized trial of three single-dose radiation therapy regimens in the treatment of metastatic bone pain. Int J Radiat Oncol Biol Phys 1998; 42(1):161-7.
http://dx.doi.org/10.1016/S03603016(98)00174-6

14. Horvat A, Kovač V, Strojan P. Radiotherapy in palliative treatment of painful bone metastases. Radiol Oncol 2009; 43(4):21324. http://dx.doi.org/ 10.2478/v10019-0090038-4

15. Ren Y, Ma L, Tian J, Zhang L, Yang K. A systematic review on different treatment methods of bone metastasis from cancers. Zhongguo Fei Ai Za Zhi 2010; 13(5):5339. http://dx.doi.org/ 10.3779/j.issn.10093419.2010.05.28

16. Shadad AK, Sullivan FJ, Martin JD, Egan LJ. Gastrointestinal radiation injury: prevention and treatment. World J Gastroenterol 2013; 19(2):199-208. http://dx.doi.org/ 10.3748/ wjg.v19.i2.199

17. Stacey R, Green JT. Radiation-induced small bowel disease: latest developments and clinical guidance. Ther Adv Chronic Dis 2014; 5(1):15-29. http://dx.doi.org/ $10.1177 / 2040622313510730$

18. Andreyev HJ, Davidson SE, Gillespie C, Allum WH, Swarbrick E. Practice guidance on the management of acute and chronic gastrointestinal problems arising as a result of treatment for cancer. Gut 2012; 61(2):179-92. http://dx.doi.org/10.1136/gutjnl-2011-300563

19. Coia LR, Myerson RJ, Tepper JE. Late effects of radiation therapy on the gastrointestinal tract. Int J Radiat Oncol Biol Phys 1995; 31(5)1213-36. http://dx.doi.org/ 10.1016/0360-3016(94)00419-L

20. Deitel M, To TB. Major intestinal complications of radiotherapy. Management and nutrition. Arch Surg 1987; 122(12):14214.

h t t p : / / d .doi.org/10.1001/ archsurg.1987.01400240069012 